\title{
Variuous Packaging Effects of Loker Telun Berasap Chili Damage During Storage
}

\author{
Eva Salvia $^{\# *}$, Lutfi Izhar $^{\#}$ dan Desy Nofriati ${ }^{\#}$ \\ ${ }^{1}$ Assessement Institute for Agricultural Technology (AIAT) Jambi \\ Jl. Samarinda Paal 5 Kota Baru \\ *Coressponding author : salviaeva84@gmail.com
}

\begin{abstract}
General characteristics of fresh horticultural products like chili, is easily get damaged after harvest. The chili declining quality and loss after harvesting occur due to ongoing respiration process. Hence, the chilies become wither or rot. This damage happens due to physical, microbiological, and physiological influences. Physical damage and yield loss can be caused by packaging uses during storage. The study aimed to determine the effect of packaging use type for Locker Telun Berasap chillies on the weight loss and damage during storage. The treatments were the commonly community packaging use types which consists of: a) polyethylene plastic (PE), b) paper and c) banana leaf. Each treatment was performed two replications and stored at room temperature. Observation parameters during storage were weight loss, and physical, physiological, microbiological damages. The lowest weight loss percentage for 12 days' storage by $P E$ packaging was $45.5 \%$. The total damage was $30 \%$ lower compared to paper and banana leaf packaging. Optimal freshness can be achieved until the 8th day of storage with physical damage only $1.03 \%$ on PE packaging. The results of the study showed that the dominant microbiological damage was found in the banana leaf packaging treatment.
\end{abstract}

Keywords_L Loker chili, damage, packaging

\section{INTRODUCTION}

Red chili (Capsicum annuum L) is one of the vegetable commodities that has high economic value. Chili is a horticultural product that is easily damaged. Consequiently, it cannot be stored for a long time due to high water content reaching $90.09 \%$, easily contaminated and attacked by microbes (Utami and Syahri, 2016). Damage occurs cause by physical, chemical, microbiological, and physiological influences. Loss of chili postharvest products ranges from 25-40\% (Muhtadi, 1992). Sugianti, et.al., (2018) stated that, chili quality lessening caused by microbes that continue to attack until in the storage stage.

One region that is famous for its local chili is named Kerinci. Some people prefer to consume local chili because they have a special taste. The local Kerinci chili is called the locker 'Telun Berasap' chili, which has been known since 2004. Local Kerinci chili production continues to rise along with the growing public demand for its availability. In account, an increasing in chili production requires good postharvest handling, maintained freshness, extended fresh times and maintained its quality of agricultural products (Trisnawati and Rubiyo, 2004).

Maintained quality by using suitable packaging method during storage, can help maintain the freshness of chili. Good packaging can prevent yield loss, maintain quality and appearance also extend ordinary product life (Rochayat and Munika, 2015). Brown (1992) states that the use of plastic films as packaging materials can extend the ledge life of fresh horticultural products. Besides the use of plastic packaging, other types of packaging that are often used by the public such as newsprint and banana leaf. Considering the shelf life and damage arising from Locker Telun Berasap chili during storage, it is important to recognize. Therefore, the purpose of this study was to determine the effect of various type packaging on the weight loss and damage to the locker Telun Baerasap chili during storage.

\section{RESEARCH METHOD}

\section{A. Place and Time}

The research was carried out in Telun Berasap Village, Gunung Tujuh District, Kerinci Regency and a study of shelf life observations was carried out at the PostHarvest Laboratory of AIAT Jambi, from July to August 2018.

\section{B. Materials and Tools}

The materials used in this study included local fresh Telun Berasap chilies, planel cloth, polyethylene 
plastic (PE) packaging, paper and banana leaf. Other tools needed were Camry brand digital scales of $5 \mathrm{~kg}$ capacity, plastic meter and digital camera.

\section{Research Methods}

The Research consisted of three treatments tested which were packaging types that were often used by the local community : a) poly-ethylene, b) paper, c) banana leaf and each treatment consisting of two replications. Place has storage for chili designated at room temperature.

\section{Data Collection and Analyzeds}

Data collected included the percentage of chili damage due to physical, physiological, and microbiological disorders. Physical damage was characterized by chili that has not intact such as broken, wrinkled and bruised. Physiological damage includes a change in the color of the chili due to physiological disorders such as brown and rot. Meanwhile, microbiological damage is injury caused by microbes that are characterized by decayed, mushy, or the appearance of fungi on the chili stalk. Observation of chili damage was done by separating any visible damage from each package; physically damaged, physiologically damaged and affected by microbes. Measurements were made related to weight loss, losses and diameter loss of chili. The data obtained were tabulated and analyzed descriptively. Calculation of weight loss, as follows:

$$
\text { (\%)Weight Loss }=\frac{\mathrm{B}_{0}-\mathrm{B}_{\mathrm{t}}}{\mathrm{B}_{0}} \times 100 \%
$$

Whereas,

Bt: Weight of fruit on day $\mathrm{n}(\mathrm{kg})$

B0: Initial weight of fruit on day $0(\mathrm{~kg})$

Determination of damage was untiring by observing chili damage level (physical, physiological and microbiological). The increase in chili damage during storage can be calculated based on the following equation:

(\%) Damage rate $=\mathrm{K} 0-\mathrm{K} 1$

Whereas,

K0: Initial Condition (on day $0=100 \%$ )

$\mathrm{K} 1$ : Damage during observation ( $\mathrm{n}$-th day)

\section{RESULT AND DISCUSSION}

\section{A. Effect of Packing Type on Chili Weight Loss during Storage \\ Loss of yield or damage can occur during storage} sign by reduction of product weight. The amount of damage can be affected by packaging used type. Decrease of Locker Telun Berasap chili weight based on variation of packaging used type during storage can be seen in Table 1 .
TABLE 1.

WEIGHT LOSS BY PACKAGING CHILI TYPE DURING STORAGE.

\begin{tabular}{llccc}
\hline \multirow{2}{*}{ No. } & \multirow{2}{*}{ Packaging Type } & \multicolumn{3}{c}{ Weight Loss (\%) } \\
\cline { 3 - 5 } & & \multicolumn{3}{c}{ Day in Storage } \\
\cline { 3 - 5 } & PE & $\mathbf{4}$ & $\mathbf{8}$ & $\mathbf{1 2}$ \\
\hline 1 & Newspaper & 15.8 & 18.6 & 45.5 \\
\hline 3 & Banana Leaf & 15.1 & 35.5 & 55.5 \\
\hline
\end{tabular}

The use of PE plastic packaging shows the lowest weight loss percentage for 12 days storage by $45.5 \%$ compared to newspaper packaging $55.5 \%$ and banana leaf $50.0 \%$. In general, weight loss occurs because at the chili postharvest time periods still conducting respiration process. Different types of packaging have different effects on holding the respiration rate. The weight loss of PE packaging is lower compared to newspaper and banana leaf packaging. This is because plastic packaging has a certain permeability that can block chili water content loss rate. Reducing weight will affect chili freshness. High weight loss can make chili become wrinkled due to loss of water content and brightness so that the appearance of chili looks unattractive. Weight loss has a large role in determining the shelf life of chili products.

Agricultural products with high weight loss will cause decreasing of freshness, chili becomes wrinkled with wrinkled skin so that the appearance becomes unappealing (Nofriati and Asni, 2015). Wrinkles on fresh products cannot be avoided during the storage period because the composition and peel surface structure can trigger damage especially mechanical damage resulting in weight loss (Lara, I. et.al. 2013). Therefore, postharvest handling must pay attention to the physical character of the product.

Some previous research verify the results related to the packaging usege in extending the freshness effect of chili. Lamona et al., (2015) stated that chili packaging with plastic film at a storage temperature of $10{ }^{\circ} \mathrm{C}$, was the most optimum in reducing amount of chili weight loss and can maintain chili freshness until the $29^{\text {th }}$ day storage. Chili storage with a box will eliminate the weight about $3.5 \%$ at a temperature of $24{ }^{0} \mathrm{C}$ every day, but only $0.5 \%$ if using a storage temperature of $8^{0} \mathrm{C}$. Whereas, if using PE packaging (polyethylene) chili weight loses will be smaller amount (Walker, 2010). Zaulia, et al. (2006) reported that the use of PE plastics can maintain the quality and freshness of chili $s$ for more than 4 weeks at $2{ }^{\circ} \mathrm{C}$ temperature storage.

\section{B. Percentage of Physical Damage during Storage}

The effect of various packaging types on the physical damage for loker Telun Berasap chili during the storage period is presented in Table 2 below. 
TABLE 2.

PERCENTAGE DAMAGE TO CHILLIES BY TYPE OF PACKAGING DURING STORAGE

\begin{tabular}{llccc}
\hline \multirow{2}{*}{ No } & \multirow{2}{*}{ Packaging Type } & \multicolumn{3}{c}{ Weight Loss (\%) } \\
\cline { 3 - 5 } & & \multicolumn{3}{c}{ Day in Storage } \\
\cline { 3 - 5 } & $\mathbf{4}$ & $\mathbf{8}$ & $\mathbf{1 2}$ \\
\hline 1 & PE & 0.83 & 1.03 & 1.84 \\
\hline 2 & Newspaper & 1.64 & 2.09 & 3.40 \\
\hline 3 & Banana Leaf & 0.97 & 1.16 & 1.46 \\
\hline
\end{tabular}

The percentage of physical damage on the $4^{\text {th }}$ day of storage did not show significant difference. However, on the $8^{\text {th }}$ to $12^{\text {th }}$ day of storage, a percentage of physical damage can be found. The greatest physical damage to newspaper packaging by $3.40 \%$ on the $12^{\text {th }}$ day was higher than the physical damage to PE packaging and banana leaf. Physical damage found during storage is wrinkles and broken. Chili becomes wrinkled as a result of weight loss that happens while chili is broken due to physical pressure from the external factors, especially on newspaper packaging. Newspaper packaging cannot protect chili perfectly, so the yield loss is quite high. The thin and easily damaged packaging texture makes frequent external physical contact such as when removing chili position during observation. The percentage of total damage during storage by type of morphological destructions can be seen in Table 3 .

TABEL 3

PERCENTAGE OF TOTAL CHILI DAMAGE BASED ON THE MORPHOLOGICAL DESTRUCTIONS TYPE DURING STORAGE

\begin{tabular}{llcl}
\hline No & $\begin{array}{l}\text { Packaging } \\
\text { Type }\end{array}$ & $\begin{array}{c}\text { Percentage } \\
(\boldsymbol{\%})\end{array}$ & $\begin{array}{c}\text { Type of } \\
\text { Morphological } \\
\text { Destruction }\end{array}$ \\
\hline 1 & PE & 30 & Rotten \\
\hline 2 & Newspaper & 60 & wrinkled and broken \\
\hline 3 & Banana Leaf & 70 & Rotten and Moldy \\
\hline
\end{tabular}

The total yield loss can reach up to $70 \%$ on the $12^{\text {th }}$ day of storage for "Loker Telun Berasap" chili which is packed using banana leaf. Damage caused by microbiological factors by chili white moldy appearance at the base of the stem and part of fruitlet. This is possible to occur as a result of storage temperature factor. The average room temperature during the study was $24^{\circ} \mathrm{C}$. High temperatures cause the rate of respiration can not be controlled. Respiratory gas accumulation on the package can stimulate microbial growth. Regarding the use of banana leaf as a packaging, Sembiring (2009) states that banana leaf packaging materials actually provides the best quality in the storage of fresh red chili in packaging when stored at $6^{\circ} \mathrm{C}$. In general, the results of the study showed that the packaging type greatly affected the level of chilli damage during the storage period. Damage was caused by mechanical, physiological and microbiological physical disorders.

\section{CONCLUSION}

Loker Telun Berasap chili Packaging type, which is stowed at room temperature, affects the yield loss during the storage period. The use of PE (polyethylene) can better reduce damage and maintain optimum freshness until the $12^{\text {th }}$ day. Banana leaf packaging usage during chili storage can be recommended because the packaging is organic and environmentally friendly. However, it's still need to obtain optimal results for study the use of various packaging types during storage at cold temperatures.

\section{ACKNOWLEDGMENT}

The authors would like to express our special thanks of gratitude to the Food Crops and Horticulture Office, Kerinci Regency and the "Telun Berasap Locker" Farmer Group, in Telun Berasap Village, Gunung Tujuh District, Kerinci Regency. Thank you very much forn all help and cooperation so that this research can be carried out well.

\section{REFERENCES}

Asgar, A. 2009. Penanganan Pascapanen Berbagai Jenis Sayuran. Makalah Linkages.

Brown, W.E. 1992. Plastic in Food Packaging. Macel Dekker, Inc. New York.

Lamona, A., Y.A. Purwanto, Sutrisno. 2015. Pengaruh jenis kemasan dan penyimpanan suhu rendah terhadap perubahan kualitas cabai merah keriting segar. Jurnal Keteknikan Pertanian 3(2): 145-152.

Lara, I, Burcu Belge and Luis F Goulou. 2013. The Fruit Cuticle as a Modular Of Postharvest Quality. J. Postharvest Biology and Technologi. $87: 103-112$.

Muchtadi, D. 1992. Fisiologi Pasca Panen Sayur-Sayuran dan Buah-Buahan. Bogor. PAU.

Nofriati, D. dan Nur Asni. 2015. Pengaruh Jenis Kemasan Dan Tingkat Kematangan Terhadap Kualitas Buah Jeruk Selama Penyimpanan Penelitian Pascapanen Pertanian.Volume12 No.2 September 2015 : 37 42.

Rochayat, Y. dan V.R. Munika, 2015. Respon Kualitas Dan Ketahanan Simpan Cabai Merah (Capsicum Annuиm L.) Dengan Penggunaan Jenis Bahan Pengemas Dan Tingkat Kematangan Buah. Jurnal Kultivasi. Vol. 14(1). 
Sembiring, N.N. 2009. Pengaruh Jenis Bahan Pengemas terhadap Kualitas Produk Cabai Merah (Capsicum annuиm L.). Tesis. Medan: Pascasarjana Universitas Sumatera Utara.

Sugianti, C. et.al., 2018. Pengaruh Hot Water Treatment (Hwt) Dan Perlakuan Pelilinan Dengan Ekstrak Jahe Terhadap Umur Simpan Cabai Merah (Capsicum Annuum L.). Jurnal Teknotan. Vol. 12 No. 1.

Trisnawati, W.,dan Rubiyo. 2004. Pengaruh Penggunaan Kemasan Dan Lama Penyimpanan Terhadap Mutu Buah Salak Bali. J. Pengkajian dan Pengembangan Teknologi Pertanian. 2004; 7(1).

Utami, R.S. dan Syahri, 2016. Kajian Pengaruh Berbagai Jenis Kemasan Terhadap Kehilangan Hasil Cabai
Selama Pengangkutan. Prosiding. Seminar Nasional Lahan Suboptimal 2016. Palembang 20-21 Oktober 2016.

Walker S. 2010. Postharvest handling of fresh chiles. NM State University. Tersedia di. .http://aces.nmsu.edu/pubs/_h/H235.pdf. Diakses pada. 28 Agustus 2019.

Zaulia, O., M. Razali, H. Aminuddin, D. Che Omar, K.H. Ng and M. Habsah. 2006. Effect of different packagings and storage temperatures on the quality of fresh-cut red chilli.J. Trop. Agric. and Fd. Sc. 34(1) : 67-76. 